\title{
Regulated phosphorylation and dephosphorylation of GAL4, a transcriptional activator
}

\author{
Lawrence M. Mylin, Jayadeva P. Bhat, and James E. Hopper \\ Department of Biological Chemistry, The Milton S. Hershey Medical Center, The Pennsylvania State University, Hershey, \\ Pennsylvania 17033 USA
}

In yeast, galactose triggers a rapid GAL4-dependent induction of galactose/melibiose regulon (GAL/MEL) gene transcription, and glucose represses this activation. We discovered that alterations in the physical state of the GAL4 protein correlate with activation and repression of the $G A L / M E L$ genes. Using Western immunoblot assay, we observe two electrophoretic forms of GAL4 protein-GAL4 and GAL4 ${ }_{\text {Ir }}$-in noninduced cells. In the absence of glucose, the addition of galactose to such cells results in the rapid appearance of a third and slowermigrating form, GAL4 ${ }_{\text {III }}$, which differs from at least GAL4, by phosphorylation. GAL80-deletion cells that constitutively transcribe galactose-responsive genes due to the lack of the GAL80 protein, an antagonist of the GAL4 protein, exhibit GAL4 II without galactose addition. Addition of glucose, which results in rapid repression of galactose gene transcription, triggers a rapid elimination of GAL4 ${ }_{\text {III }}$ and an increase in GAL4 II . Cycloheximide experiments provide evidence that the galactose- and glucose-triggered GAL4 protein mobility shifts are due to post-translational modification. $\mathrm{GAL}_{\mathrm{III}}$ is labeled with $\left[{ }^{32} \mathrm{P}\right] \mathrm{phosphate}$ in vivo; in vivo ${ }^{35} \mathrm{~S}-$ labeled GAL4 $4_{\text {III }}$ could be converted by phosphatase treatment in vitro to GAL4. We present a model proposing that phosphorylation state changes in the GAL4 protein are key to modulating its activity.

[Key Words: GAL4; Saccharomyces cerevisiae; phosphorylation; transcriptional activator; carbon catabolite repression]

Received March 21, 1989; revised version accepted June 14, 1989.

In the yeast Saccharomyces cerevisiae, transcription of the galactose/melibiose regulon $(G A L / M E L)$ genes is enhanced dramatically by the addition of galactose. This induction is controlled in part by the functional interplay of three primary regulators-the GAL4, GAL80, and GAL3 proteins (for reviews, see Oshima 1982; Johnston 1987).

GAL4 is a transcriptional activator that binds specifically to a consensus DNA site, UASgal, which is associated with all known galactose-inducible promoters in yeast (Bram and Kornberg 1985; Giniger et al. 1985; Bram et al. 1986; Bajwa et al. 1988). UASgal binding locates the GAL4 protein properly for activating transcription (Keegan et al. 1986). The transcriptional activation domain of GAL4 clearly is separable from its DNAbinding domain (Brent and Ptashne 1985; Keegan et al. 1986; Ma and Ptashne 1987a). The GAL80 protein blocks GAL4-activated transcription in the absence of galactose (Torchia et al. 1984; Yocum and Johnston 1984). This appears to involve direct GAL80 proteinGAL4 protein interaction (Lue et al. 1987). It is well established that the 80-4 interaction does not block GAL4 protein binding to UASgal (Lohr and Hopper 1985; Giniger et al. 1985; Selleck and Majors 1987). Galactose addition in conjunction with GAL3 protein activity triggers a rapid alteration of the functional interplay between the GAL4 and GAL80 proteins to allow high-level
GAL4-dependent transcription (Winge and Roberts 1948; Torchia and Hopper 1986).

$G A L / M E L$ gene expression is repressed severely in response to glucose metabolism (for review, see Carlson 1987). The binding of the GAL4 protein to UASgal sequences is reduced severely in glucose-grown cells (Bram and Kornberg 1985; Giniger et al. 1985; Lohr and Hopper 1985; Selleck and Majors 1987), but the basis for this effect has not been established. Whatever the mechanism(s) involved, it is clear that glucose repression does not require the GAL80 protein (Torchia et al. 1984).

Despite a rather well-defined genetic and molecular picture of the $G A L / M E L$ regulon, precise mechanisms of induction and repression operating in this system remain unclear. In particular, it has not been known whether physical changes in either the GAL4 and/or GAL80 proteins occur in response to galactose or glucose.

We discovered that GAL4 protein exists as multiple electrophoretic species in yeast cells that are unamplified for its production. The number and electrophoretic mobility of GAL4 protein species detected by Western blotting of yeast extracts varies reproducibly in response to conditions known to affect $G A L / M E L$ transcription. One form of GAL4 protein, GAL4 ${ }_{\mathrm{II}}$, appears to arise by phosphorylation. This form appears only under conditions in which GAL80 protein activity is relieved, 
whether by galactose addition or deletion of the GAL80 gene. GAL4 $4_{\text {mI }}$ is converted rapidly to a more rapidly migrating form in response to glucose in either the presence or absence of GAL80. We present evidence consonant with the notion that this glucose response is the result of dephosphorylation of GAL4 $4_{\mathrm{III}}$.

\section{Results}

GAL4 protein is altered physically in response to galactose

By immunoblot analysis of GAL4 in extracts of yeast cells, we detect at least three electrophoretic forms of GAL4 protein, which we designate as GAL4 ${ }_{\mathrm{I}}, \mathrm{GAL}_{\mathrm{u}}$, and GAL4 $4_{\mathrm{III}}$, with apparent sizes, respectively, of 100 , 105 , and $108 \mathrm{kD}$ (see below). These forms are detected in both wild-type cells and cells that are amplified for GAL4 protein production.

GAL4 $_{\text {I }}$ and GAL4 $4_{\text {II }}$ are observed in extracts prepared from SC252 (wild-type) cells grown on the noninducing carbon sources glycerol and lactic acid (gly/lac; Fig. 1B, lanes 1 and 5). Addition of galactose to the culture results in the appearance of $\mathrm{GAL}_{\mathrm{m}}$ as well as the disappearance of GAL4 ${ }_{\text {II }}$ within 30 min (Fig. 1B, lane 6). If galactose remains in the culture for a longer period of time (galactose catabolism being well established; Adams 1972; Broach 1979; Yarger et al. 1984; Torchia and Hopper 1986), we again detect GAL4 (Fig 1B, lanes 8 and 9, which represent 2 and $4 \mathrm{hr}$ post galactose addition, respectively). Although GAL4 $4_{\text {III }}$ and GAL4 $4_{\text {II }}$ are not clearly resolved in lanes 8 and 9 (Fig. 1B), the increased width of the upper band indicates that both are present.
In contrast to the data described above from galactose addition experiments ( $4 \mathrm{hr}$ or less duration), we see a different pattern for wild-type GAL80 cells grown on galactose for several generations (referred to as 'long-term galactose-grown' in the discussion|. Figure 2 illustrates that GAL4 $4_{\text {III }}$ is not detected in wild-type cells grown for several generations on galactose containing media (lane wt; compare with lane 80D, which shows GAL4 $4_{\text {III }}$.

\section{Deletion of GAL80 allows formation of GAL4 $4_{I I I}$ in the absence of galactose}

Because deletion of the GAL80 gene (gal80D) results in constitutive activation of $G A L / M E L$ transcription, we compared the electrophoretic profiles of GAL4 protein from strains differing genetically only at the $G A L 80$ locus. Deletion of GAL80 produced a dramatic effect: GAL4 III was prominent in extracts from gal80D but not GAL80 cells grown on noninducing gly/lac media (cf. lanes 1 or 5 between Fig. 1B,Cl. Thus, a form of GAL4, GAL4 III which appears in GAL80 cells only in response to galactose, appears in gal80D cells in the absence of galactose. Clearly then, the GAL 80 protein prevents an alteration of the GAL4 protein that normally occurs in response to galactose.

The results illustrated in Figure 1C indicate further that GAL80 is not the only activity involved in modulating the abundance of GAL4 $4_{\mathrm{m}}$. For example, addition of galactose to the gal $80 \mathrm{D}$ gly/lac culture resulted in a transient disappearance of GAL4 $4_{\text {m }}$ (Fig. 1C, cf. lanes 6 or 7 with lane 5). GAL4 ${ }_{\mathrm{mI}}$ was reduced to undetectable levels within $30 \mathrm{~min}$ after galactose addition, but was visible again within $2 \mathrm{hr}$ (Fig. 1C, cf. lanes 6 or 7 with
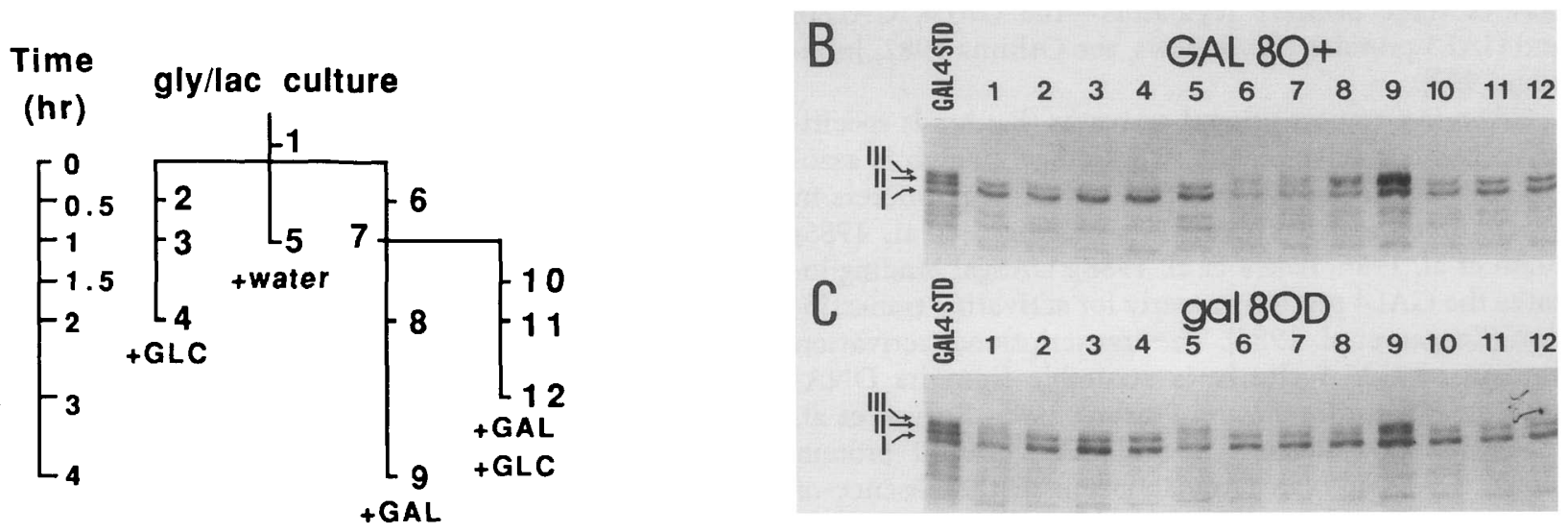

Figure 1. Immunoblotting analysis reveals carbon source and GAL80-dependent physical alterations in GAL4 protein. Gly/lac cultures of wild-type yeast strain SC252 and the nearly isogenic gal80D derivative SC285 were split into three subcultures each following an initial sampling. Subcultures received $2 \%$ glucose (+GLC), $2 \%$ galactose (+GAL), or glass-distilled water (+ water). Incubation continued, and culture samples were taken as indicated (see $A$, below). Glucose was added to a portion of the $+\mathrm{GAL}$ culture after $1 \mathrm{hr}$ $(+\mathrm{GAL}+\mathrm{GLC})$, and incubation continued with sampling as indicated. Extracts were prepared by Method A. Equal volumes (20 $\mu$ l) of extracts were used for immunoblotting. $(A)$ Experimental flow chart. Samples (designated 1-12 below 'gly/lac culture') correspond to lane designations in $B$ and $C$. Time after splitting of the initial culture is indicated in hours on the accompanying time scale. $(B)$ Immunoblot analysis using wild-type yeast strain SC252. GAL4 $(\mathrm{I}), \mathrm{GAL}_{\text {II }}$ (II), and GAL4 (IIII) are indicated for the GAL4 STD lane. (C) Immunoblot analysis using gal80D yeast strain SC285. 


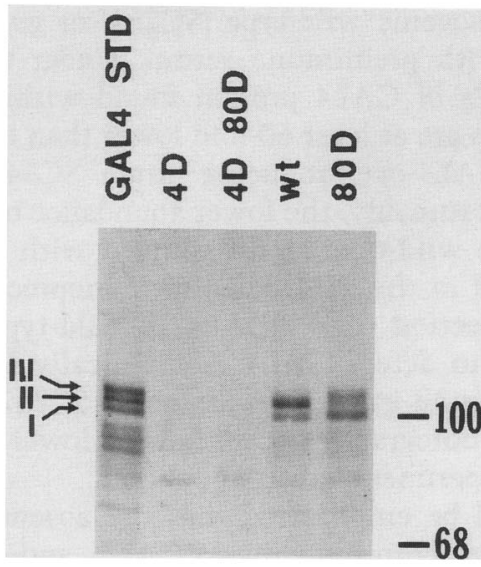

Figure 2. Immunoblotting analysis of GAL4 protein in GAL80 and gal $80 D$ cells grown for several generations in the presence of galactose. Yeast strains SC413 (lane 4D), SC414 (lane $4 D$ $80 D$ ), SC252 (lane wt), and SC285 (lane 80D) were grown at least five generations in gly/lac media containing $2 \%$ galactose. Extracts were prepared by Method A. Equivalent amounts of Coomassie Blue-staining protein were assayed by immunoblotting. Molecular weights of standards are indicated in kilodaltons. Electrophoretic forms of GAL4 (I, II, III) are indicated in the GAL4 STD lane by arrows.

lanes 8 or 9|. This transient disappearance of $\mathrm{GAL4}_{\mathrm{m}}$ does not occur in the absence of GAL1, GAL7, and GAL10, genes encoding the enzymes required for galactose catabolism (L.M. Mylin and J.E. Hopper, unpubl.).

\section{$G A L 4_{I I I}$ is reduced severely in response to glucose catabolism}

Severe glucose repression of $G A L / M E L$ transcription occurs even in the absence of the GAL/MEL-specific negative regulator, GAL80. We reasoned that if GAL4 either expedites or results from the rapid induction phase, its abundance may by reduced by glucose catabolite repression. However, we could not test this notion using glucose-grown strains because we were unable to detect any forms of GAL4 protein in glucose-grown strains unless GAL4 production was amplified (data not shown). To test for a glucose response, we added glucose to cells in which we could detect GAL4 protein. Glucose addition to wild-type (SC252) cells where GAL4 II previously was induced by galactose resulted in a rapid disappearance of GAL4 III (Fig. 1B, cf. lane 7 with lanes 10-12; see Fig. 1A for time and carbon source information). The glucose response was equally dramatic in a gal80D mutant growing in the absence of galactose. GAL4 dis disappeared within 30 min following glucose addition to gly/lac-grown gal80D cells (Fig. 1C, cf. lanes 2 or 3 with lane 5). When glucose was added in the presence of galactose, GAL4 ${ }_{\text {III }}$ did not reappear within $2 \mathrm{hr}$, kinetics observed for GAL4 $4_{\text {III }}$ reappearance without glucose addition (Fig. 1C, cf. lanes 8 and 12). Clearly then, the glucose-triggered elimination of GAL4 $4_{\mathrm{II}}$ occurs independently of GAL80, a protein that blocks GAL4 $4_{\text {III }}$ appearance in gly/lac-grown cells.
Post-translational events account for physical alterations of GAL4

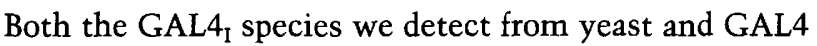
protein produced in $E$. coli comigrate (Fig. 3) and exhibit the electrophoretic mobility expected of the full-length GAL4 protein (predicted molecular mass of 99,350 daltons; Laughon and Gesteland 1984). GAL4 II and GAL4 $4_{\text {III }}$ migrate more slowly than GAL4 ${ }_{1}$ (e.g., Figs. 1-3 and $4 \mathrm{~B})$.

To determine whether post-translational events might give rise to the multiple electrophoretic forms of GAL4, we employed an inhibitor of protein synthesis. Previous work (Perlman and Hopper 1979) established that inhibition of protein synthesis with cycloheximide does not prevent the normal rapid galactose- triggered appearance of GAL transcripts. Using cycloheximide in a similar protocol here, we observe that both GAL4 II and GAL4 appear to form at the expense of GAL4 $4_{I}$ upon galactose addition in the absence of protein synthesis (Fig. 3). In Figure 3, both $\mathrm{GAL}_{4}$ and GAL4 ${ }_{\mathrm{II}}$ are observed prior to cycloheximide addition, the GAL4 $4_{\text {II }}$ band being the more intense of the two (Fig. 3, lanes -1$)$. By $1 \mathrm{hr}$ in the presence of cycloheximide (Fig. 3, + cycloheximide lane 0), the intensity of the two bands had changed to favor GAL4 . A similar change was not observed in the control (cf. Fig. 3, lanes 0 ). Within 30 min of galactose addition to both control and cycloheximide-containing flasks, a shift in intensity favoring more slowly migrating forms of GAL4 was observed (Fig. 3, lanes 0.5). In each case, the 'upward' intensity shift included an increase in both $\mathrm{GAL}_{n}$ and $\mathrm{GAL} 4_{m}$, although GAL4 $4_{m}$ appears less abundant (and probably for this reason appears less clearly resolved from GAL4II) in the presence of cycloheximide (Fig. 3, + GAL lanes 1). Addition of glucose to both control and cycloheximide-containing flasks removed GAL4 $4_{\mathrm{II}}$ and increased the intensity of GAL4 $4_{\mathrm{II}}$ and $\mathrm{GAL} 4_{\mathrm{I}}$

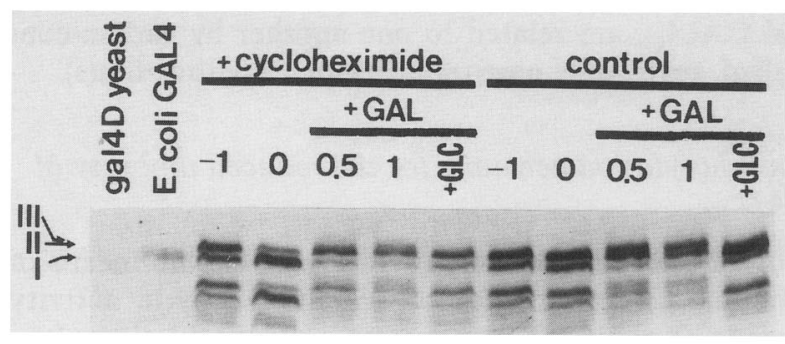

Figure 3. Immunoblotting evidence for post-translational modification of GAL4 protein. ADH1GAL4 GAL80 yeast strain SC386 was grown in gly/lac media. The culture was sampled (lane -1$)$ and split into two flasks. One flask was supplemented with $100 \mu \mathrm{g} / \mathrm{ml}$ cycloheximide (Perlman and Hopper 1979). After $1 \mathrm{hr}$, zero time samples (lane 0 ) were removed from each flask, galactose was added $(+\mathrm{GAL})$, and incubation continued with samples removed after 0.5 and $1 \mathrm{hr}$. Immediately after the 1-hr sampling, glucose was added, and final samples (lane $+G L C)$ were removed $30 \mathrm{~min}$ later. Whole-cell extracts were prepared (method B), and $40 \mu \mathrm{g}$ of protein was loaded in each lane. A 0.5-ng amount of GAL4 protein produced in E. coli mixed with extract from $\mathrm{SC} 413$ (lane gal4D yeast) was included as a standard (lane E. coli GAL4). 


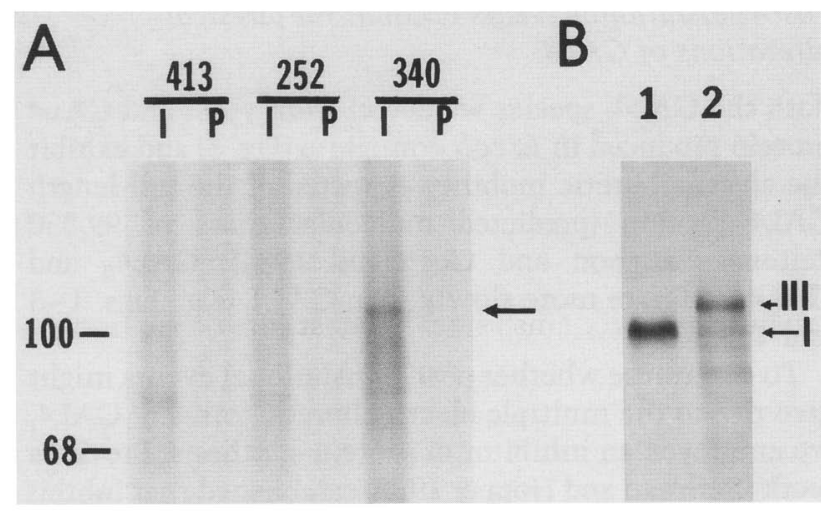

Figure 4. Immunoprecipitation and Western blotting analysis of yeast cell extracts labeled in culture with $\left[{ }^{32} \mathrm{P}\right]$ orthophosphate. Extracts from yeast strains SC413, SC252, and SC340 labeled in culture with [32 P]orthophosphate (see Materials and methods) were analyzed by immunoprecipitation $(A)$ and by immunoblotting $(B) .(A)$ Autoradiogram of electrophoresed ${ }^{32} \mathrm{P}$ immunoprecipitates. (Lane $I$ ) Immune serum; (lane $P$ ) preimmune serum. Immunoprecipitation reactions were prepared using 77,000 Cerenkov cpms; volumes of primary extracts required were 100, 52, and $49 \mu \mathrm{l}$ from SC413, SC252, and SC340, respectively. The positions of prestained molecular weight standards are indicated in kilodaltons. The position of $\left.{ }^{32} \mathrm{P}\right] \mathrm{GAL} 4$ is indicated by the arrow to the right. Exposure was for $24 \mathrm{hr}$ without an intensifying screen. (B) Immunoblotting analysis of ${ }^{32} \mathrm{P}$-labeled extract prepared from strain SC340. An 8- $\mu \mathrm{l}$ aliquot of primary extract from ${ }^{32} \mathrm{P}$-labeled SC340 was analyzed by immunoblotting (lane 2). A 0.5 -ng amount of GAL4 produced in an $E$. coli strain mixed with unlabeled extract from SC413 was included as a standard (lane 1). The positions of electrophoretic forms GAL4 ${ }_{\text {III }}$ (III) and GAL4 ${ }_{I}$ (I) are indicated. GAL4 $4_{\text {II }}$ was not visible under these conditions. $A$ and $B$ are not aligned for molecular mass comparisons.

bands (cf. lanes 1 to + GLC within each set). These results suggest that GAL4 ${ }_{\text {I }}$ and GAL4 ${ }_{\text {II }}$ as well as GAL4 and $\mathrm{GAL} 4_{\mathrm{m}}$, are related to one another by carbon-controlled, reversible, post-translational modification(s).

\section{Phosphorylation accounts for the reduced mobility of $G A L 4_{I I I}$}

Protein phosphorylation provides a reversible means of modulating both conformation and catalytic activity (Sprang et al. 1988), and protein phosphorylation often alters mobility during denaturing SDS-PAGE. For example, phosphorylation of a yeast transcriptional regulator, the heat shock transcription factor (HSF), was shown to reduce its migration during SDS-PAGE, as well as correlate with increased transcription from HSF sensitive promoters (Sorger and Pelham 1988).

We find that GAL4 is phosphorylated in yeast (Fig. 4A). A ${ }^{32}$ P-labeled protein band displaying electrophoretic mobility characteristic of GAL4 $4_{\mathrm{m}}$ was detected by immunoprecipitation of extracts from a GAL4-overproducing yeast strain (SC340) upon galactose induction in the presence of $\left[{ }^{32} \mathrm{P}\right]$ orthophosphate. This band is identified as a form of GAL4 protein because it was not de- tected in isogenic wild-type (SC252) or gal4D (SC413) cells, or with preimmune serum. Under these conditions, levels of GAL4 protein found within wild-type SC252 cells are at least 60 -fold lower than in the nearly isogenic GAL4-overproducing strain SC340 (data not shown). Presumably, the lower abundance of GAL4 protein in the wild-type strain coupled with the level of background in the ${ }^{32} \mathrm{P}$-labeled immunoprecipitates prevented detection of [ $\left.{ }^{32} \mathrm{P}\right] \mathrm{GAL} 4$ in wild-type cells. We were able to detect GAL4 metabolically labeled with $\left[{ }^{35} S\right]$ methionine in galactose-induced SC252 cells upon extended fluorography because of the lower background in those experiments (data not shown).

It should be emphasized that the absence of ${ }^{32} \mathrm{P}-1 \mathrm{a}-$ beled species corresponding to GAL4 $4_{\text {II }}$ and/or $\mathrm{GAL}_{\mathrm{I}}$ in the immunoprecipitation experiment shown in Figure $4 \mathrm{~A}$ does not indicate that these species were not ${ }^{32} \mathrm{P}$-labeled in the same experiment. As illustrated in Figure $4 \mathrm{~B}$, the relative abundances of GAL4 ${ }_{\text {I }}$ and GAL4 $4_{\text {II }}$ (not visible) are reduced noticeably in the GAL4 overproducer during galactose induction in the phosphate-limiting media. For this reason, they would not be visible above the background even if they were ${ }^{32} \mathrm{P}$-labeled. The lowered relative abundance of $\mathrm{GAL}_{\mathrm{I}}$ and GAL4 ${ }_{\mathrm{II}}$ observed during galactose induction of the GAL4-overproducing strain (SC340) in the phosphate-limiting media used for these experiments is reproducible.

Covalent linkage of the ${ }^{32} \mathrm{P}$ label to GAL4 $4_{\mathrm{m}}$, the major GAL4 band detected by immunoprecipitation, was confirmed by two-dimensional paper electrophoresis after limited acid hydrolysis (Fig. 5). Phosphoserine and phosphothreonine, but not phosphotyrosine, were detected.

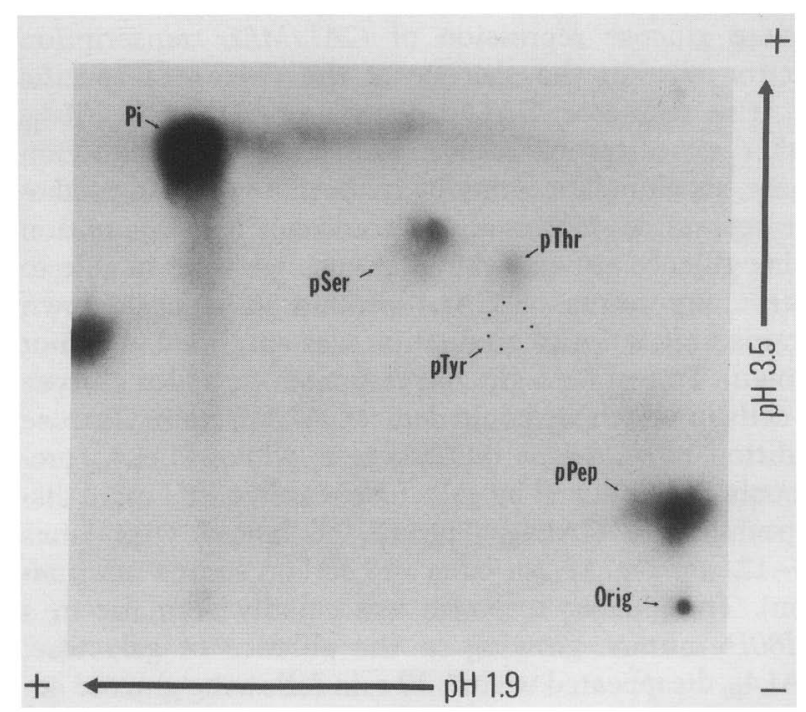

Figure 5. Phosphoamino acid analysis of ${ }^{32} \mathrm{P}$-labeled GAL4 protein. Aliquots of primary extracts from SC413 and SC340 (see Fig. 4) were immunoprecipitated and analyzed by two dimensional paper electrophoresis following excision and partial acid hydrolysis of the major [32P]GAL4 band. Direction of electrophoresis at the indicated $\mathrm{pH}$ is given by the arrow. (Pi) Free label; (pPep) incompletely hydrolyzed peptides; (Orig) origin. Pi and pPep were assigned according to Cooper et al. (1983). 
In a parallel control experiment employing the nearly isogenic gal4 deletion strain SC413, extraction and analysis of the corresponding gel slice revealed 50 -fold less phosphoamino acids and phosphopeptides (data not shown). Phosphoamino acid analyses on forms GAL4 and GAL4 ${ }_{\text {II }}$ could not be done because these forms were not detected in the ${ }^{32} \mathrm{P}$-labeling experiment (see above).

\section{Phosphatase treatment increases the electrophoretic mobility of GAL4}

Phosphatase treatment of ${ }^{32} \mathrm{P}$ - and ${ }^{35} \mathrm{~S}$-labeled immunoprecipitates was carried out to determine whether the labeled band migrating as GAL4 $4_{\text {III }}$ could be dephosphorylated to yield electrophoretic forms $\mathrm{GAL}_{\mathrm{I}}$ or GAL4 $4_{\mathrm{II}}$. Immunoprecipitates of GAL4 from radiolabeled, galactose-induced SC340 were treated with calf intestinal alkaline phosphatase (CIP) in the presence and absence of inorganic phosphate, a phosphatase inhibitor (Fernley 1971). In the absence of inhibitor, CIP treatment increased the mobility of the $\left[{ }^{35} \mathrm{~S}\right] \mathrm{GAL} 4$ from the mobility characteristic of GAL4 mII to that of GAL4 ${ }_{I}$ (Fig. 6). ${ }^{32} \mathrm{P}$-Labeled GAL4 $4_{\text {m }}$ was also sensitive to phosphatase treatment, in that it was no longer visible following phosphatase treatment in the absence of added inhibitor. Whether the ${ }^{32} \mathrm{P}$-labeled material visible after phosphatase treatment in the absence of inhibitor is physically identical to GAL4 $4_{1}$ produced in vivo remains unclear. Although phosphatase treatment apparently did remove

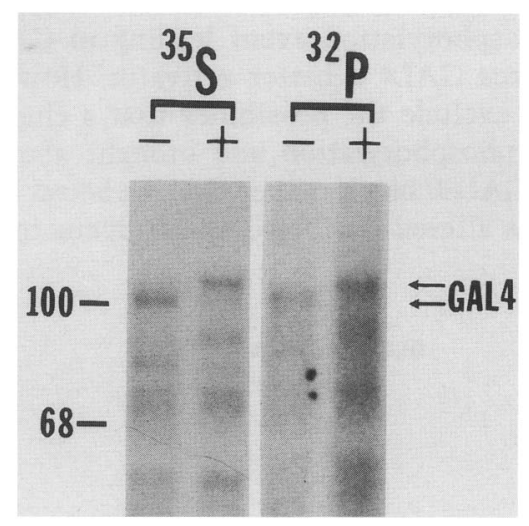

Figure 6. Alkaline phosphatase treatment increases the electrophoretic mobility of metabolically labeled GAL4 protein. Primary extracts (see Materials and methods) from both ${ }^{32} \mathrm{P}$ and ${ }^{35}$ S-labeled galactose-induced, GAL4-overproducing strain SC340 were immunoprecipitated using anti-GAL4 serum, and the solubilized immunoprecipitates were treated with calf intestinal alkaline phosphatase in the presence (lane + ) or absence (lane -) of $10 \mathrm{~mm} \mathrm{NaPO}_{4}$. The ${ }^{32} \mathrm{P}$-labeled primary extract was as described for Fig. 4. SC340 was labeled with $\left.{ }^{35} \mathrm{~S}\right]$ methionine by adding the isotope to a gly/lac culture 17.6 $\mu \mathrm{Ci} / \mathrm{ml}$ media) 1 -hr after the galactose $(2 \%)$. A 1 -hr labeling period was followed by a $15-\mathrm{min}$ chase with $1 \mathrm{~mm}$ unlabeled methionine. Exposures were $-70^{\circ} \mathrm{C}$ for 29 days without an intensifying screen $\left({ }^{35} \mathrm{~S}\right)$, or for $15 \mathrm{hr}$ with screen $\left({ }^{32} \mathrm{P}\right)$. Positions of molecular weight standards are indicated in kilodaltons. Radiolabeled species migrating at the positions of GAL4 $4_{\text {III }}$ and GAL4 are indicated by the upper and lower arrows, respectively. one or more phosphates altering the electrophoretic mobility of GAL4 protein, it is certainly possible that other phosphorylated residues that do not affect GAL4's electrophoretic mobility are refractory to CIP treatment. We have not yet succeeded in clearly resolving a labeled species that comigrates with GAL4 $4_{\text {II }}$ by limited phosphatase treatment of GAL4 $4_{\mathrm{II}}$ in vitro. Whether $\mathrm{GAL} 4_{\mathrm{II}}$ is also related to GAL4, by phosphatase-sensitive covalent modification remains to be demonstrated.

\section{Discussion}

\section{GAL4 $4_{I I}$ correlates with high-level expression of $\mathrm{GAL} /$} MEL genes

This work reveals a striking correlation between the presence of $\mathrm{GAL}_{\mathrm{m}}$ and the expression state of the system. This correlation is realized in terms of GAL80 effects, galactose effects, and the glucose effect.

We find that GAL4 $4_{\text {III }}$ is prominent in gal8OD cells grown in gly/lac, but is not detected in GAL80 wild-type cells grown long term on galactose. These cell types and growth conditions have been compared previously for $G A L / M E L$ expression, and it is evident that GAL/MEL expression in gal80D cells grown on gly/lac is twofold higher than that in wild-type GAL80 cells grown long term on galactose (Torchia et al. 1984). An additional example of the correlation in terms of a GAL80 effect is our finding that $\mathrm{GAL}_{\mathrm{mI}}$ is prominent in gal80D but not GAL80 cells grown long term on galactose media. In comparing the expression levels in gal80D and GAL80 strains grown long term on galactose, Torchia et al. (1984) observed 1.5-fold higher galactokinase (GAL1) and 1.2-fold higher $\alpha$-galactosidase (MEL1) levels (enzymes and transcripts) in the gal80D cells.

The GAL4 II pattern exhibits a remarkable parallel to expression state changes during the early-phase induction response in GAL80 cells. In cells grown on gly/lac the $G A L / M E L$ gene transcripts are at very low levels, but in response to galactose addition the levels increase 100to 1000-fold (for reveiw, see Johnston 1987) and attain maximal levels within 1-2 hr (Yarger et al. 1984; Torchia and Hopper 1986). We detect only $\mathrm{GAL4}_{\mathrm{I}}$ and GAL4 $4_{\text {II }}$ in gly/lac-grown, noninduced $G A L 80$ wild-type cells. By $30 \mathrm{~min}$ after galactose addition, $\mathrm{GAL}_{\mathbf{n}}$ has been replaced by GAL4 4 II. However, within $2-4 \mathrm{hr}$ of galactose addition $\mathrm{GAL}_{\mathrm{I}}$ reappears, and some time after 4 hr GAL4 $4_{\text {III }}$ begins to disappear and is no longer detected in GAL80 cells grown long term on galactose. But even this post-induction disappearance of GAL4 $\mathrm{m}$ appears to correlate with an expression state change. The GAL1 transcript reaches a maximal level by $1 \mathrm{hr}$ after galactose addition and decreases to about $75 \%$ of the maximal level within $3 \mathrm{hr}$ after galactose addition (Yarger 1981).

The occurrence of GAL4 $4_{\text {m }}$ associated with gal 80 cells grown in either gly/lac or long term on galactose, as well as its appearance in $G A L 80$ cells in response to galactose, is suppressed dramatically in response to glucose. The disappearance of GAL4 ${ }_{\mathrm{II}}$ is correlated with the transition to the glucose-repressed state. That glucose addi- 
tion rapidly and severely reduces synthesis of the $G A L /$ $M E L$ regulon enzymes was well documented some time ago (Adams 1972; Kew 1974). By recent quantitative experiments employing a GAL10-LacZ fusion construct, $\mathrm{Ma}$ and Botstein (1986) demonstrated a 50-fold decrease in $L a c Z$ expression in response to a shift from galactose to galactose plus glucose. Our experiments using shifts from galactose to galactose plus glucose show that GAL4 III disappears within $30 \mathrm{~min}$ after the addition of glucose to either 1-hr galactose-induced wild-type cells or gal80D cells growing in gly/lac.

Finally, the transient disappearance of GAL4 $4_{\mathrm{m}}$ that we observe upon galactose addition to gal80D cells grown in gly/lac may strengthen this correlation further. This transient disappearance most likely reflects transient self carbon catabolite repression, a phenomenon well documented in bacteria (Magasanik 1961), because we do not observe the transient disappearance of GAL4 ${ }_{\text {III }}$ in gal80D gal1D gal7D gal10D cells, which lack galactose catabolic enzymes.

On the basis of striking consistency in the occurrence of GAL4 $4_{\text {III }}$ relative to the expression state of the system, we propose that the presence of GAL4 $4_{\mathrm{mI}}$ is correlated with maximal or nearly maximal GAL4-dependent transcription.

\section{$G A L 4_{I I I}$ is a phosphoprotein and arises at the expense of $G A L 4_{I}$}

In response to galactose, $\mathrm{GAL}_{\mathrm{mII}}$ appears to form posttranslationally, either directly or indirectly at the expense of GAL4 $4_{1}$. From the experiments reported here it is unclear whether or not GAL4 $4_{\text {II }}$ is an intermediate leading from $\mathrm{GAL}_{1}$ to $\mathrm{GAL} 4_{\mathrm{II}}$. The event producing electrophoretic-form GAL4 $4_{\mathrm{m}}$ is most likely phosphorylation because the GAL4 protein can be labeled in vivo with ${ }^{32} \mathrm{P}$, and immunoprecipitated, ${ }^{35} \mathrm{~S}^{-}$-labeled GAL4 ${ }_{\mathrm{m}}$ is converted by in vitro phosphatase treatment to a faster electrophoretic form migrating with GAL4 $4_{\mathrm{I}}$. On the basis of these results and the results presented above, we propose that the transcriptional activator GAL4 undergoes carbon-responsive and GAL80-responsive phosphorylation and dephosphorylation in vivo.

\section{Glucose triggers alteration of the GAL4 protein}

Our results provide direct evidence for the physical change of a transcriptional activator protein brought about by carbon catabolite or glucose repression. We show here that glucose addition rapidly alters GAL4 protein in vivo in a manner consistent with dephosphorylation. The effect does not require GAL80 protein and therefore most likely represents at least one point at which the GAL4 protein is directly affected by glucose repression control.

Interestingly, our results differ from those of Cherry et al. (1989), who present indirect evidence that glucose triggers a phosphorylation inactivation of ADR1, a transcriptional activator of the yeast $A D H 2$ gene. In the case of ADR1, phosphorylation is proposed to occur in re- sponse to the presence of glucose, the opposite of what we propose for GAL4. Examination of the predicted amino acid sequences of the ADR1 and GAL4 proteins provides yet another contrast. ADR 1 contains a consensus phosphorylation site for cAMP-dependent protein kinase that appears important for proper regulation of ADRl-dependent transcription (Cherry et al. 1989). Our analysis of the published GAL4 sequence does not reveal such a motif. Instead, GAL4 appears to contain multiple sequences that might serve as phosphorylation sites for cAMP-independent casein kinases I and/or II (Hathaway and Traugh 1982; Edelman et al. 1987).

In light of our results, we note that several potential phosphate acceptors occur within a segment of the GAL4 protein that is important for transcriptional activation (activation region II; Ma and Ptashne 1987a), and within the carboxy-terminal 30 amino acids required for repression by GAL80 protein (Johnston et al. 1987; Ma and Ptashne 1987b). These candidate sites are currently under investigation.

Proposed model: regulated phosphorylation modulates GAL4 activity

Overall, our data provide evidence for post-translational changes in the physical state of the GAL4 protein that occur in response to conditions known to affect GAL4 protein-dependent transcription. The different physical states of GAL4 protein indicated by the multiple electrophoretic forms observed most likely represent GAL4 species of differing activity. We favor a model (Fig. 7) in which a phosphorylation event leading to GAL4 $4_{\text {III }}$ formation makes GAL4 a better activator. However, our data do not exclude the possibility that a change independent of phosphorylation and brought about by relieving the GAL 80 block makes GAL4 a better activator, and that this altered form of GAL4 happens to be more

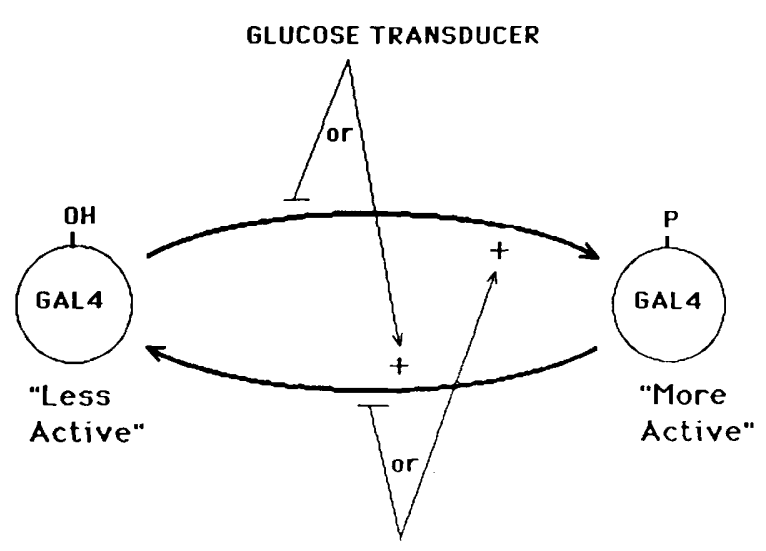

GALACTOSE TRANSDUCER

Figure 7. A model for phosphorylation/dephosphorylation control of GAL4 activity. The model implies that there is a protein kinase and protein phosphatase that interconvert GAL4 between less active and more active forms. Galactose and glucose transducers include sensory and effector genes required for the interconversions. 
readily phosphorylated. It also remains to be determined which GAL4-specific functions are affected by posttranslational modification (DNA binding or activation) and what protein modifies GAL4.

\section{Materials and methods}

Yeast strains and growth media

Genetic variants of yeast strain SC252 (SJ21R; Johnston and Hopper 1982) were created by lithium acetate transformation (Ito et al. 1983) using linearized plasmid DNA (Rothstein 1983). Strain SC285 was constructed by replacement of the wild-type GAL80 locus with a gal80 construct lacking an internal $0.6-\mathrm{kb}$ BglII fragment. YEp13 was used as a cotransforming vector (Broach et al. 1979). LEU ${ }^{+}$transformants were screened for constitutive MEL1 expression by a chromogenic overlay assay (Post-Beittenmiller et al. 1984), and the deletion was confirmed by Southern analysis (Southern 1975) of EcoRI-cut genomic DNA (T. Torchia and L. Mylin, unpubl.).

Yeast strain SC386 (TTD16-1C), a generous gift of T. Torchia, was obtained by sporulation (Sherman et al. 1986) of diploid 4063-2 (Torchia and Hopper 1986). SC386 is GAL4 GAL80 gal $(1,10,7) D$ [ADH1GAL4-URA3]. The integrated ADH1GAL4 construct was described previously (Johnston et al. 1986; Baker et al. 1987); the radiation-induced deletion allele of the GAL1 GAL10 GAL7 cluster, gal $(1,10,7) D$, was isolated by D. Hawthorne and has been characterized by St. John and Davis (1981).

Strains SC413 (gal4 deletion in SC252) and SC340 (SC252 containing an integrated construct in which the GAL4-coding region is fused to the GAL10 promoter, and overproduces GAL4 protein upon galactose addition) have been described elsewhere (Schultz et al. 1987; Mylin et al. 1989). GAL4 was disrupted in SC285 with LEU2 as described (Mylin et al. 1989), producing strain SC414.

Yeast strains were maintained on YEPD liquid media (Torchia and Hopper 1986). The $5 \times$ succinate $/ \mathrm{NaOH}$-buffered synthetic liquid media used for most experiments was essentially as described (Mylin et al. 1989), except that $0.05 \%$ dextrose was omitted from noninducing gly/lac media, and leucine was included at $300 \mathrm{mg} /$ liter for synthetic complete media. Unless otherwise indicated, experiments were initiated using gly/lacgrown cultures $\left(\mathrm{OD}_{600}=0.15-0.3\right)$ shaken at $30^{\circ} \mathrm{C}$. Glucose (GLC) or galactose (GAL) were added as concentrated stock solutions to final concentrations of $2 \%(\mathrm{wt} / \mathrm{vol})$, as indicated in the figure legends. Metabolic labeling with $\left.{ }^{35} \mathrm{~S}\right]$ methionine (Amersham, SJ.1015) was performed in the same media lacking methionine after galactose addition.

Cells were labeled with [32P]orthophosphate (ICN, 64014) in phosphate-adjusted, citrate-buffered, synthetic complete liquid media (Toh-E et al. 1973) supplemented with $1 / 35 \times$ phosphate-depleted YEP (Bostian et al. 1980), 3\% glycerol, and 2\% ethanol. Cultures were incubated with the isotope $11 \mathrm{mCi} / \mathrm{ml}$ culture) for $2 \mathrm{hr}$ in this media, followed by addition of $2 \%$ galactose for another $2 \mathrm{hr}$ to induce GAL4 protein overproduction.

\section{Preparation of yeast extracts and immunoblotting}

Yeast extracts used for immunoblot analysis were prepared essentially as described (Schultz et al. 1987), except that $20 \mu \mathrm{g} / \mathrm{ml}$ aprotinin (Sigma) was included in breaking buffers (method A). Alternatively, unfractionated cell homogenates were solubilized by addition of $5 \times$ electrophoresis sample buffer (Schultz et al. 1987) directly to the cell homogenates prior to separation from the glass beads, heated, and clarified by centrifugation (method B).

Immunoblotting analysis was performed as described (Mylin et al. 1989), except that electrophoresis proceeded for $3 \mathrm{hr}$, blots were incubated overnight at $4^{\circ} \mathrm{C}$ in blocking solution, and incubations with primary and secondary antibodies were increased to 4 and $2 \mathrm{hr}$, respectively. Extracts prepared from a yeast strain displaying electrophoretic forms GAL4 ${ }_{\text {I }}$ GAL4 $_{\text {III }}$ and GAL4 were included as standards on most blots. GAL4 protein produced in an E. coli strain (Johnston et al. 1986; Mylin et al. 1989 ) was mixed with extract from SC413 for use on some blots. Protein estimations were performed as described (Schultz et al. 1987). Prestained molecular weight standards (-Highs; Bethesda Research Laboratories) were included on all gels; the molecular masses indicated are the apparent sizes given by the supplier.

\section{Preparation and immunoprecipitation of metabolically} labeled yeast extracts

Yeast strains were labeled in culture as described above. Cells were separated from culture media by centrifugation after chilling on ice, resuspended and pelleted twice in ice-cold water, and stored as pellets at $-70^{\circ} \mathrm{C}$ after freezing on dry ice. Cell homogenates were prepared by intermittent vortexing of the cell pellets with $0.5 \mathrm{ml}$ of $0.45-\mathrm{mm}$ glass beads and $0.3 \mathrm{ml}$ of buffer A [50 mM NaPO 4 (pH 7.2), $5 \mathrm{~mm}$ EDTA, 1 mM DTT, 1 mM PMSF, $0.2 \mathrm{mM} \mathrm{Na}_{3} \mathrm{VO}_{4}, 50 \mathrm{~mm} \mathrm{NaF}, 2 \mu \mathrm{M}$ pepstatin A, 0.6 $\mu \mathrm{M}$ leupeptin, and $20 \mu \mathrm{g} / \mathrm{ml}$ aprotinin]. Primary extracts were prepared from unfractionated homogenates by addition of 0.3 $\mathrm{ml}$ of buffer B (buffer A containing $2 \%$ SDS), heated at $100^{\circ} \mathrm{C}$ for $6 \mathrm{~min}$ with intermittent vortexing, and clarified by centrifugation at room temperature at $50,000 \mathrm{~g}$ for $10 \mathrm{~min}$.

Reaction mixtures for immunoprecipitation were prepared as follows using aliquots of extracts containing equal amounts of total trichloroacetic acid (TCA)-precipitable radioactivity. Each tube received a $0.1-\mathrm{ml}$ total of labeled primary extract and combined buffers $A$ and $B, 0.9 \mathrm{ml}$ of buffer $\mathrm{C}[50 \mathrm{~mm} \mathrm{NaPO} / 4 \mathrm{pH}$ 7.2), $130 \mathrm{~mm} \mathrm{NaCl}, 1 \%$ Triton $\mathrm{X}-100,1 \%$ sodium deoxycholate, $1.1 \mathrm{mg} / \mathrm{ml}$ of bovine serum albumin, and $10 \mathrm{mM}$ EDTA], and 8 $\mu l$ of either preimmune or anti-GAL4 serum (Mylin et al. 1989). Tubes were agitated gently at $4^{\circ} \mathrm{C}$ for $2 \mathrm{hr}$. A total of $20 \mu \mathrm{l}$ of Pansorbin (Calbiochem) was then added, and agitation continued for $2 \mathrm{hr}$. Immunoprecipitates were collected by centrifugation at $10,000 \mathrm{~g}$ for $5 \mathrm{~min}$ at $4^{\circ} \mathrm{C}$, washed twice by resuspension in buffer $\mathrm{C}$ containing $0.2 \%$ SDS $(\mathrm{C}-0.2 \%)$ and pelleting through $\mathrm{C}-0.2 \%$ containing $1 \mathrm{M}$ sucrose, washed once with resuspension in $\mathrm{C}-0.2 \%$, rinsed without resuspension with cold water, solubilized by heating in $60 \mu \mathrm{l}$ of $1 \times$ electrophoresis sample buffer for $7 \mathrm{~min}$ at $100^{\circ} \mathrm{C}$, and clarified by centrifugation at $10,000 \mathrm{~g}$ for $5 \mathrm{~min}$. Then $10-\mu \mathrm{l}$ aliquots were electrophoresed as described above. Gels were fixed in $50 \%$ methanol, $10 \%$ acetic acid for $2 \mathrm{hr}$, followed by $10 \%$ methanol, $7 \%$ acetic acid for $2 \mathrm{hr}$, rinsed with water, dried, and exposed to Kodak XAR5 film. Gels containing ${ }^{35}$ S-labeled proteins additionally were impregnated with Autofluor (National Diagnostics) prior to drying.

\section{Phosphoamino acid analysis}

Solubilized immunoprecipitates were fractionated on preparative mini slab gels. [ $\left.{ }^{32} \mathrm{P}\right] \mathrm{GAL} 4$ protein was located by autoradiography, excised (as well as the corresponding region from a gal4D control gel), electroeluted using an Elutrap (Schleicher \& Schuell), concentrated by precipitation with TCA, and rinsed with ethanol and diethyl ether. Precipitates were solubilized by 
addition of $15 \mu \mathrm{l}$ of $0.1 \mathrm{~N} \mathrm{NaOH}$ followed by $0.6 \mathrm{ml}$ of constant boiling $\mathrm{HCl}$ (Pierce), heated at $110^{\circ} \mathrm{C}$ for $2 \mathrm{hr}$, and dried under vacuum. Next, $100 \mu \mathrm{l}$ of $\mathrm{pH} 1.9$ electrophoresis buffer containing $5 \mu \mathrm{g}$ each of unlabeled phosphoserine, phosphothreonine, and phosphotyrosine (pSer, pThr, and pTyr, respectively) were added to each hydrolysate. The majority of the ${ }^{32} \mathrm{P}$ radioactivity was solubilized after extended vortexing at room temperature. An additional $10 \mu \mathrm{g}$ of each unlabeled phosphoamino acid standard was added to the samples, which then were spotted on individual $20 \times 20-\mathrm{cm}$ sheets of Whatman $3 \mathrm{MM}$ paper. Flatbed electrophoresis was performed in the first dimension at $\mathrm{pH} 1.9$ for $50 \mathrm{~min}$ (3750 volts), and in the second at $\mathrm{pH} 3.5$ for $20 \mathrm{~min}$ as described (Cooper et al. 1983). The positions of unlabeled standards were determined with ninhydrin before exposing the papers to X-ray film with intensifying screens for 2 weeks at $-70^{\circ} \mathrm{C}$.

\section{Alkaline phosphatase treatment of immunoprecipitates}

Immunoprecipitates (see above) were solubilized in $1 \times$ electrophoresis sample buffer, clarified by brief centrifugation, and aliquots diluted 10-fold into $20 \mu \mathrm{l}$ phosphatase reaction mixtures. Phosphatase reaction mixtures contained $50 \mathrm{mM}$ Tris $(\mathrm{pH} 8.0)$, $0.1 \mathrm{~mm}$ EDTA, $1 \mathrm{mM}$ DTT, $1 \mathrm{~mm}$ PMSF, $20 \mu \mathrm{g} / \mathrm{ml}$ Aprotinin, $0.6 \mu \mathrm{M}$ leupeptin, $2 \mu \mathrm{M}$ pepstatin $\mathrm{A}, 1 \mathrm{mM} \mathrm{MgCl}$, and 4 units of calf intestinal alkaline phosphatase (Boehringer-Mannheim, 713023 ) in addition to components supplied by the now 10fold-diluted electrophoresis sample buffer. Sodium phosphate $10 \mathrm{~mm}$ was included as indicated. Incubations were preformed at $37^{\circ} \mathrm{C}$ for $1 \mathrm{hr}$, followed by the addition of 0.25 volumes of fresh electrophoresis sample buffer, heating, and electrophoresis.

\section{Acknowledgments}

This work was supported by U.S. Public Health Service grant R01 27925 to J.H. We wish to thank T. Torchia for yeast strain SC386, and W. Bajwa, M. Billingsley, and L. Schultz for valuable comments during the course of this work. We thank A. Hopper, C. Hill, W. Hendrickson, and D. Spector for critical reading of the manuscript.

\section{References}

Adams, B.G. 1972. Induction of galactokinase in Saccharomyces cerevisiae: Kinetics of induction and glucose effects. J. Bacteriol. 111: 308-315.

Bajwa, W., T.E. Torchia, and J.E. Hopper. 1988. Yeast regulatory gene GAL3: Carbon regulation; $\mathrm{UAS}_{\mathrm{Gal}}$ elements in common with GAL1, GAL2, GAL7, GAL10, GAL80, and $M E L 1$; encoded protein strikingly similar to yeast and Eshericia coli galactokinases. Mol. Cell. Biol. 8: 3439-3447.

Baker, S.M., S.A. Johnston, J.E. Hopper, and J.A. Jaehning. 1987. Transcription of multiple copies of the yeast GAL7 gene is limited by specific factors in addition to GAL4. Mol. Gen. Genet. 208: 127-134.

Bostian, K.A., J.M. Lemire, L.E. Cannon, and H.O. Halverson. 1980. In vitro synthesis of repressible yeast acid phosphatase: Identification of multiple mRNAs and products. Proc. Nat1. Acad. Sci. 77: 4504-4508.

Bram, R.J., N.F. Lue, and R.D. Kornberg. 1986. A GAL family of upstream activating sequences in yeast: Roles in both induction and repression of transcription. EMBO J. 5: 603608.

Bram, R.J. and R.D. Kornberg. 1985. Specific binding to far up- stream activating sequences in polymerase II promoters. Proc. Natl. Acad. Sci. 82: 43-47.

Brent, R. and M. Ptashne. 1985. A eukaryotic transcriptional activator bearing the DNA specificity of a prokaryotic repressor. Cell 43: 729-736.

Broach, J.R. 1979. Galactose regulation in Saccharomyces cerevisiae. The enzymes encoded by the $G A L 7,10,1$ cluster are coordinately controlled and separately translated. I. Mol. Biol. 131: 41-53.

Broach, J.R., J.N. Strathern, and J.B. Hicks. 1979. Transformation in yeast: Development of a hybrid cloning vector and isolation of the CAN1 gene. Gene 8: 121-133.

Carlson, M. 1987. Regulation of sugar utilization in Saccharomyces species. J. Bacteriol. 169: 4873-4877.

Cherry, I.R., T.R. Johnson, C. Dollard, J.R. Shuster, and C.L. Denis. 1989. Cyclic AMP-dependent protein kinase phosphorylates and inactivates the yeast transcriptional activator ADRl. Cell 56: 409-419.

Cooper, J.A., B.M. Sefton, and T. Hunter. 1983. Detection and quantification of phosphotyrosine in proteins. Methods Enzymol. 99: 387-402.

Edelman, A.M., D.K. Blumenthal, and E.G. Krebs. 1987. Protein serine/threonine kinases. Annu. Rev. Biochem. 56: 576613.

Fernley, H.N. 1971. Mammalian alkaline phosphatases. In The Enzymes, vol. 3 (ed. P.D. Boyer), pp. 417-447. Academic Press, New York.

Giniger, E., S.M. Varnum, and M. Ptashne. 1985. Specific DNA binding of GAL4, a positive regulatory protein of yeast. Cell 40: $767-774$.

Hathaway, G.M. and J.A. Traugh. 1982. Casein kinases-Multipotential protein kinases. Curr. Top. Cell. Regul. 21: 101127.

Ito, H., Y. Fukudua, K. Murata, and A. Kimura. 1983. Transformation of intact yeast cells treated with alkali cations. I. Bacteriol. 153: 163-168.

Johnston, M. 1987. A model fungal gene regulatory mechansim: The GAL genes of Saccharomyces cerevisiae. Microbiol. Rev. 51: 458-476.

Johnston, S.A. and J.E. Hopper. 1982. Isolation of the yeast regulatory gene $G A L 4$ and analysis of its dosage effects on the galactose/melibiose regulon. Proc. Natl. Acad. Sci. 79: 6971-6975.

Johnston, S.A., M.I. Zavortink, C. Debouck, and J.E. Hopper. 1986. Functional domains of the yeast regulatory protein GAL4. Proc. Natl. Acad. Sci. 83: 6553-6557.

Johnston, S.A., J.M. Salmeron, and S.S. Dichner. 1987. Interaction of positive and negative regulatory proteins in the galactose regulon of yeast. Cell 50: 143-146.

Keegan, L., G. Gill, and M. Ptashne. 1986. Separation of DNA binding from the transcription-activating function of a eukaryotic regulatory protein. Science 231: 699-703.

Kew, O.M. 1974. 'Regulation of galactose and melibiose utilization in Saccharomyces: A genetic and physiological study' Doctoral thesis, University of Washington.

Laughon, A. and R.F. Gesteland. 1984. Primary structure of the Saccharomyces cerevisiae GAL4 gene. Mol. Cell. Biol. 4: 260-267.

Lohr, D. and J. Hopper. 1985. The relationship of regulatory proteins and DNase I hypersensitive sites in the yeast GAL1-10 genes. Nucleic Acids Res. 13: 8409-8423.

Lue, N.F., D.I. Chasman, A.R. Buchman, and R.D. Kornberg. 1987. Interaction of GAL4 and GAL80 gene regulatory proteins in vitro. Mol. Cell. Biol. 7: 3446-3451.

$\mathrm{Ma}, \mathrm{H}$. and D. Botstein. 1986. Effects of null mutations in the 
hexokinase genes of Saccharomyces cerevisiae on catabolite repression. Mol. Cell. Biol. 6: 4046-4052.

Ma, J. and M. Ptashne. 1987a. Deletion analysis of GAL4 defines two transcriptional activating segments. Cell 48: $847-$ 853.

1987b. The carboxyl 30 amino acids of GAL4 are recognized by GAL80. Cell 50: 113-119.

Magasanik, B. 1961. Catabolite repression. Cold Spring Harbor Symp. Quant. Biol. 26: 249-256.

Mylin, L.M., L.D. Schultz, and J.E. Hopper. 1989. A regulated GAL4 expression cassette providing controllable and high level output from high copy galactose promotors in yeast. Methods Enzymol. (in press).

Oshima, Y. 1982. Regulatory circuits for gene expression: The metabolism of galactose and phosphate. In The molecular biology of the yeast Saccharomyces metabolism and gene expression, (ed. J.N. Strathern, E.W. Jones, and J.R. Broach), pp. 159-180. Cold Spring Harbor Laboratory, Cold Spring Harbor, New York.

Perlman, D. and J.E. Hopper. 1979. Constitutive synthesis of the GAL4 protein, a galactose pathway regulator in Saccharomyces cerevisiae. Cell 16: 89-95.

Post-Beittenmiller, M.A., R.W. Hamilton, and J.E. Hopper. 1984. Regulation of basal and induced levels of the MEL1 transcript in Saccharomyces cerevisiae. Mol. Cell. Biol. 4: $1238-1245$.

Rothstein, R. 1983. One step gene disruption in yeast. Methods Enzymol. 101: 202-211.

Schultz, L.D., K.J. Hofmann, L.M. Mylin, D.L. Montgomery, W. Ellis, and J.E. Hopper. 1987. Regulated overproduction of the GAL4 gene product greatly increases expression from galactose-inducible promoters on multi-copy expression vectors in yeast. Gene 61: 123-133.

Selleck, S.B. and J.E. Majors. 1987. In vivo DNA-binding properties of a yeast transcription activator protein. Mol. Cell. Biol. 7: 3260-3267.

Sherman, F., G.R. Fink, and J.B. Hicks. 1986. Laboratory course manual for methods in yeast genetics. Cold Spring Harbor Laboratory, Cold Spring Harbor, New York.

Sorger, P.K. and H.R.B. Pelham. 1988. Yeast heat shock factor is an essential DNA-binding protein that exhibits temperature-dependent phosphorylation. Cell 54: 855-864.

Southern, E.M. 1975. Detection of specific sequences among DNA fragments separated by gel electrophoresis. I. Mol. Biol. 98: 503-517.

Sprang, S.R., K.R. Acharya, E.J. Goldsmith, D.I. Stuart, K. Varvill, R.J. Fletterick, N.B. Madsen, and L.N. Johnson. 1988. Structural changes in glycogen phosphorylase induced by phosphorylation. Nature 336: 215-221.

St. John, T.P. and R.W. Davis. 1981. The organization and transcription of the galactose gene cluster of Saccharomyces. I. Mol. Biol. 152: 285-315.

Torchia, T.E. and J.E. Hopper. 1986. Genetic and molecular analysis of the GAL3 gene in the expression of the galactose/melibiose regulon of Saccharomyces cerevisiae. Genetics 113: 229-246.

Torchia, T.E., R.W. Hamilton, C.L. Cano, and J.E. Hopper. 1984. Disruption of regulatory gene GAL80 in Saccharomyces cerevisiae: Effects on carbon-controlled regulation of the galactose/melibiose pathway genes. Mol. Cell. Biol. 4: $1521-1527$.

Toh-E, A., Y. Ueda, S. Kakimoto, and Y. Oshima. 1973. Isolation and characterization of acid phosphatase mutants in Saccharomyces cerevisiae. J. Bacteriol. 113: 277-287.

Winge, O. and C. Roberts. 1948. Inheritance of enzymatic char- acters in yeast and the phenomenon of long-term adapta tion. C. R. Trav. Lab. Carsberg. Ser. Physiol. 24: 264-315.

Yarger, J.G. 1981. "Regulation of inducible GAL1 enzyme synthesis in the galactose pathway of Saccharomyces cerevisiae." Doctoral thesis, Brandeis University.

Yarger, J.G., H.O. Halverson, and J.E. Hopper. 1984. Regulation of galactokinase (GAL1) enzyme accumulation in Saccharomyces cerevisiae. Mol. Cell. Biochem. 61: 173-182.

Yocum, R.R. and M. Johnston. 1984. Molecular cloning of the GAL80 gene from Saccharomyces cerevisiae and characterization of a gal80 deletion. Gene 32: 75-82. 


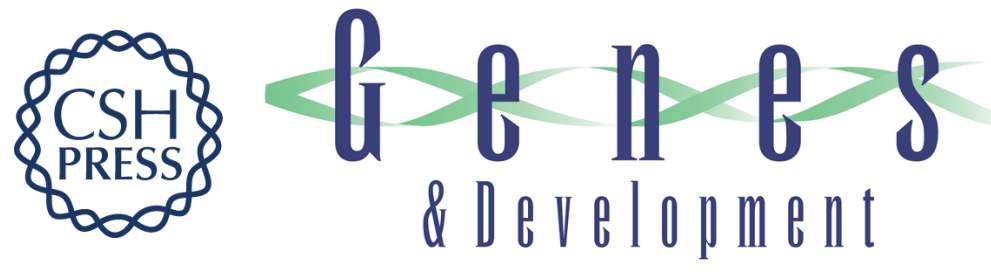

\section{Regulated phosphorylation and dephosphorylation of GAL4, a transcriptional activator.}

L M Mylin, J P Bhat and J E Hopper

Genes Dev. 1989, 3:

Access the most recent version at doi:10.1101/gad.3.8.1157

References This article cites 43 articles, 18 of which can be accessed free at: http://genesdev.cshlp.org/content/3/8/1157.full.html\#ref-list-1

License

Email Alerting

Service

Receive free email alerts when new articles cite this article - sign up in the box at the top right corner of the article or click here.

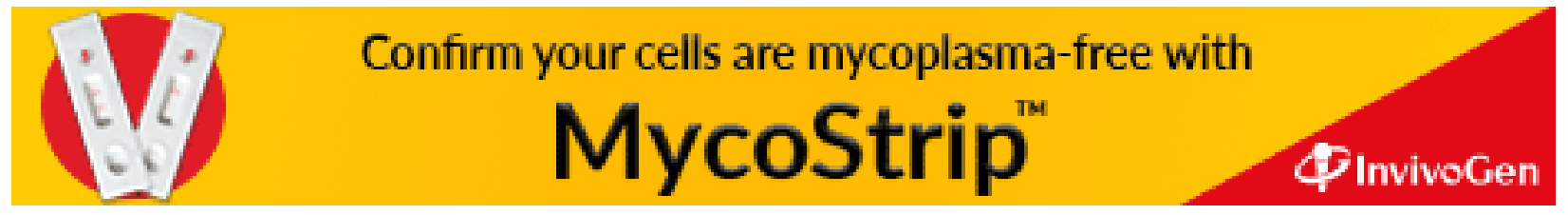

